\title{
Az intertemporális diszkontálás és a társadalmi diszkontráta etikai vonatkozásai*
}

\author{
Somogyvári Márta
}

A tanulmány a diszkontálás etikai vonatkozásait vizsgálja az intertemporális döntések elökészitése során, és ennek befolyását a közösségi beruházások költség-haszon elemzésére. A középpontban azok a gazdaságfilozófiai és etikai megfontolások állnak, amelyek a diszkontálást mint napi pénzügyi tevékenységet alapozzák meg. A szerző megkísérli a kardinális és a diszkontált utilitarista etikai felfogás közötti látszólagos logikai ellentmondás feloldását. A Ramsey-formulában szereplő paraméterek értékeinek megállapításával kapcsolatos előfeltételek vizsgálatával mutatja be, hogy sem az intertemporális beruházások esetében alkalmazott társadalmi diszkontráta, sem a potenciálisan környezetterhelő beruházásoknál alkalmazott piaci diszkontráta megállapitásának mai gyakorlata nem alkalmas a hosszú távú közösségi, illetve a környezetterhelö magánbefektetések értékelésére.

Journal of Economic Literature (JEL) kódok: A13, D63, H43, Q58

Kulcsszavak: diszkontálás, társadalmi diszkontráta, Ramsey-formula, utilitarizmus, gazdasági etika

\section{Bevezetés}

A gazdasági és üzleti élet döntései ugyan látszólag a jövőről szólnak, de valójában mindig egy viszonylag statikus, a jelennel megegyező, vagy abból könnyen levezethető jövőkép vezérli a döntéshozókat. Ez a belátható, kiszámítható jövő, ahol a ciklusok újra meg újra lejátszódnak, a trendek folytatódnak, a trendváltozások könnyen megjósolhatók, a katasztrófák enyhék és hosszú távon elhanyagolhatók. Ezzel szemben állnak azok a szituációk, amikor, akár rövid távon is, nagy, kiszámíthatatlan változásokkal kell számolni, s nem tudjuk, hogy az általunk elképzelt, vagy el nem képzelt szcenárió következik-e be. Ebbe a második csoportba tartoznak azok az esetek is, amikor olyan hosszú távról beszélünk, aminek a keretfeltételeit már nem tudjuk - vagy nem merjük - megbecsülni sem. Arra nem szeretünk gondolni, hogy a beláthatatlan, kiszámíthatatlan jövő, amit ösztönösen a nagyon hosszú távval azonosítunk, az időhorizontunkon akár néhány év múlva is megjelenhet.

\footnotetext{
* A jelen kiadványban megjelenő írások a szerzők nézeteit tartalmazzák, ami nem feltétlenül egyezik a Magyar Nemzeti Bank hivatalos álláspontjával.

Somogyvári Márta egyetemi docens a Pécsi Tudományegyetem Közgazdaságtudományi Kara Kvantitativ Menedzsment Intézetében. E-mail: somogyv@ktk.pte.hu
}

A magyar nyelvű kézirat első változata 2018. március 19-én érkezett szerkesztőségünkbe.

DOI: http://doi.org/10.25201/HSZ.17.3.109132 
Miért lényeges a különbségtevés a kétféle jövő között? Azért, mert a közgazdászok, amikor a jövőre kiható döntésekről beszélnek, legyen az akár belátható, akár beláthatatlan, szinte ösztönösen nyúlnak ugyanahhoz az eszközhöz, a diszkontáláshoz. A klasszikus közgazdasági megközelítés szerint kockázatról akkor beszélhetünk, ha kvantifikálni tudjuk az adott tényezőt, míg a bizonytalanság esetében nem tudjuk mérni a valószínúséget és/vagy teljesen bizonytalan a kimenet (Knight 1921). Ezzel az elméletben jól megkülönböztethető két fogalommal szemben áll a beruházások értékelésének napi gyakorlata. Amikor diszkontálásról beszélünk, akkor pénzáramokról van szó, ami azt jelenti, hogy valaki valamiképpen - akár „objektív” akár „Szubjektív" alapon (Bélyácz 2010) - már megbecsülte az adott tényezőt, legyen az egy beruházás nyomán keletkező bevétel a 20. évben, vagy a költségeket befolyásoló infláció mértéke a beruházás teljes időhorizontja alatt. Egyik sem belátható, mégis mind a kettőt megbecsüljük ahhoz, hogy kimondhassuk a beruházásról, megtérül-e, vagy sem. A bizonytalanságot pedig a diszkontálással próbáljuk eloszlatni. A diszkontálás így válasz arra a kérdésre, hogy „hogyan kezeljük a jövőt", s közben egy könnyen használható, gyakorlati iránymutatás a pénzügyi kalkulációk elkészítésére. A diszkontálás segítségével megadott általános válasz úgy hangzik: próbáljuk meg úgy kezelni, mint a jelent, csak „,vegyünk vissza” egy kicsit az értékéből. Ami a kívülálót meglepheti, az az, hogy mind a belátható, mind a látszólag kiszámítható, de bármely pillanatban beláthatatlanná váló jövő esetében ugyanahhoz a megoldáshoz nyúl a legtöbb elméleti és gyakorlati gondolatmenet.

A standard diszkontálási módszerek magától értetődők a belátható jövőre vonatkozó politikák és intézkedések kidolgozásában. A diszkontálás hatásmechanizmusa ugyanolyan, mint a kamatos kamaté. Azé a kamatos kamaté, amely rövid távon a szakemberek számára még talán racionálisan felfogható, de hosszú távon már számukra is irreálisnak tűnő eredményeket hoz. Elég csak arra gondolnunk, hogy egy száz évvel ezelőtti 5 százalékos kamatos kamatra befektetett 1000 USD összeg mára már 131501 USD-re növekedett volna. Ugyanez a példa a magyar forintra már nem adható meg, hiszen itt a 100 évvel ezelőtti bankot már nem találjuk meg (amire az USA-t nézve még van esélyünk), s a 100 évvel ezelőtti fizetőeszköz is más volt, hiszen közben pénzcserék, hiperinflációk, gazdasági válságok, rendszerváltások és különböző egyéb katasztrófák színesítették a magyar gazdasági viszonyokat.

A beláthatatlan jövő esetében már azok számára is kérdéseket vet fel a diszkontálás, akik ezt a napi gyakorlatban alkalmazzák, hiszen a jövő ilyen mechanikus leértékelése felveti a jelen és jövő generációk közötti konfliktusok problémáját. Látva, hogy hosszú távon még a viszonylag kis diszkontráta változása is milyen jelentős különbségeket okoz a jövőbeli pénzáramok értékelésében, joggal érezhetjük úgy, hogy ez a számítási módszer valahol torzít, s ellentétes az ösztöneinkkel, vagy talán a józan ésszel is. 
A diszkontálás látszólag csak egy mellékes pénzügytechnikai döntésnek tűnik, s magától értetődő a használata. Éppen ez a természetesség az, ami elhalványítja a tényt, hogy a diszkontálás és a diszkontráta mértéke alapvetően befolyásolja döntéseinket mind a közjószágok, mind a magánjószágok előállításához szükséges beruházások tervezése során, s eldönti, hogy mely beruházások valósulhassanak meg, s melyekre mondjuk azt, hogy gazdaságtalanok.

A diszkontálás hatását a beláthatatlan jövőre legjobban a klímaváltozással kapcsolatos intézkedések költség-haszon elemzésével lehet érzékeltetni. Ugyan nem tudjuk, hogy a klímaváltozás pontosan milyen szcenárió szerint valósul meg, de feltételezzük, hogy mind az egyes nemzetgazdaságok szintjén, mind globálisan veszteségeket fog okozni. Amikor Stern (2007) és nem sokkal később Nordhaus (2008) megpróbálta számba venni ezeket a lehetséges gazdasági hatásokat, ugyanolyan alapfeltételezésekkel éltek a klímaváltozás hatásait, a gazdasági rendszer meghatározó tényezőit és fő paramétereit tekintve (Weisbach - Sunstein 2009). A legnagyobb különbség közöttük egy látszólag kis technikai kérdés, mégpedig az, hogy hogyan határozzák meg a diszkontrátát. Stern alacsony, 1,4 százalékos diszkontrátát javasolt (később ezt felemelte 2 százalékra), Nordhaus magas, 5,5 százalékos diszkontráta mellett érvelt. A két érték a jövő kétfajta értékelését jelenti. Az 1,4 százalékos diszkontrátával számolva a klímaváltozás költségei 100 év múlva 53-szor nagyobbak, mint ha 5,5 százalékkal számolunk. 200 év múlva már 2800-szoros a különbség (Weisbach - Sunstein 2009). A két szerző különböző intézkedéseket javasol a klímaváltozás hatásainak elhárítására. Stern szerint azonnal költséges intézkedésekbe kell kezdenünk az üvegházhatást okozó gázok emissziójának csökkentésére, a károk elhárítására. Ezzel szemben Nordhaus álláspontja az, hogy nem szükségesek a gyors intézkedések, miután az azokat megalapozó nagyon alacsony diszkontráta nem öszszeegyeztethető a mai piaci viszonyokkal (Nordhaus 2006). Szerinte az energiarendszerünk lassú, fokozatos átalakítása is elegendő. A gyors, azonnali intézkedések nagyon költségesek és viszonylag kis hasznot hoznak.

\section{A diszkontálás hatása az aszimmetrikus költségszerkezetű projektekre}

A beláthatatlan jövő diszkontálása különösen érdekes azoknál a hosszú életciklusú beruházásoknál, amelyeknél a költségek és bevételek eloszlása az élettartam során aszimmetrikus. Amikor például egyes energiatermelési technológiákat értékelünk, akkor a nettó jelenérték számításánál hátrányba kerülnek azok a projektek, ahol nagyok a kezdeti beruházási költségek és utána kicsik a müködtetés, karbantartás és lebontás költségei, azokkal a projektekkel szemben, ahol a költségek eloszlása egyenletesebb. Szisztematikusan jelentkezik ez a különbség, a megújuló (szél, víz, nap, geotermia) és a fosszilis energiahordozókra alapuló beruházások (szén, gáz, olaj) között. Amikor ez a pénzügyi értékelés párosul egy morális ítélettel, miszerint 
a fosszilis a „rossz”, a megújuló a „jó”, akkor mindenki támogatásért kiált, hogy a megújuló energiák piacra törésének korlátait ellensúlyozni lehessen. Az éretlen, az innovációs fázisban levő technológia esetében indokoltak a magas szubvenciók, ha a társadalom úgy látja, hogy át akar térni egy másik energetikai paradigmára. Amint ezek a technológiák elérik az érettséget, vagyis ugyanolyan, vagy akár alacsonyabb áron képesek előállítani pl. a villamos energiát, mint a hálózati ár, vagy az adott projektben a beruházás már megtérült, akkor a támogatás már járadékként fogható fel. Ez a járadék olyan meg nem szolgált ellentételezés, ami megakadályozza, hogy a társadalom más innovációk vagy más társadalmi célok megvalósítására fordítsa az erőforrásait.

A jövő generációkra rótt terhek értékelése során különleges esetet jelentenek az olyan, a környezetet a jövőben extrém módon terhelő beruházások, amikor nagyon nagyok a lebontás költségei. Az 1. ábra azt mutatja meg, hogy különböző élettartamú projektek esetében a leszerelési költségek hányad részét kell figyelembe venni a projekt nettó jelenértének kiszámításakor különböző diszkontráták alkalmazásánál.

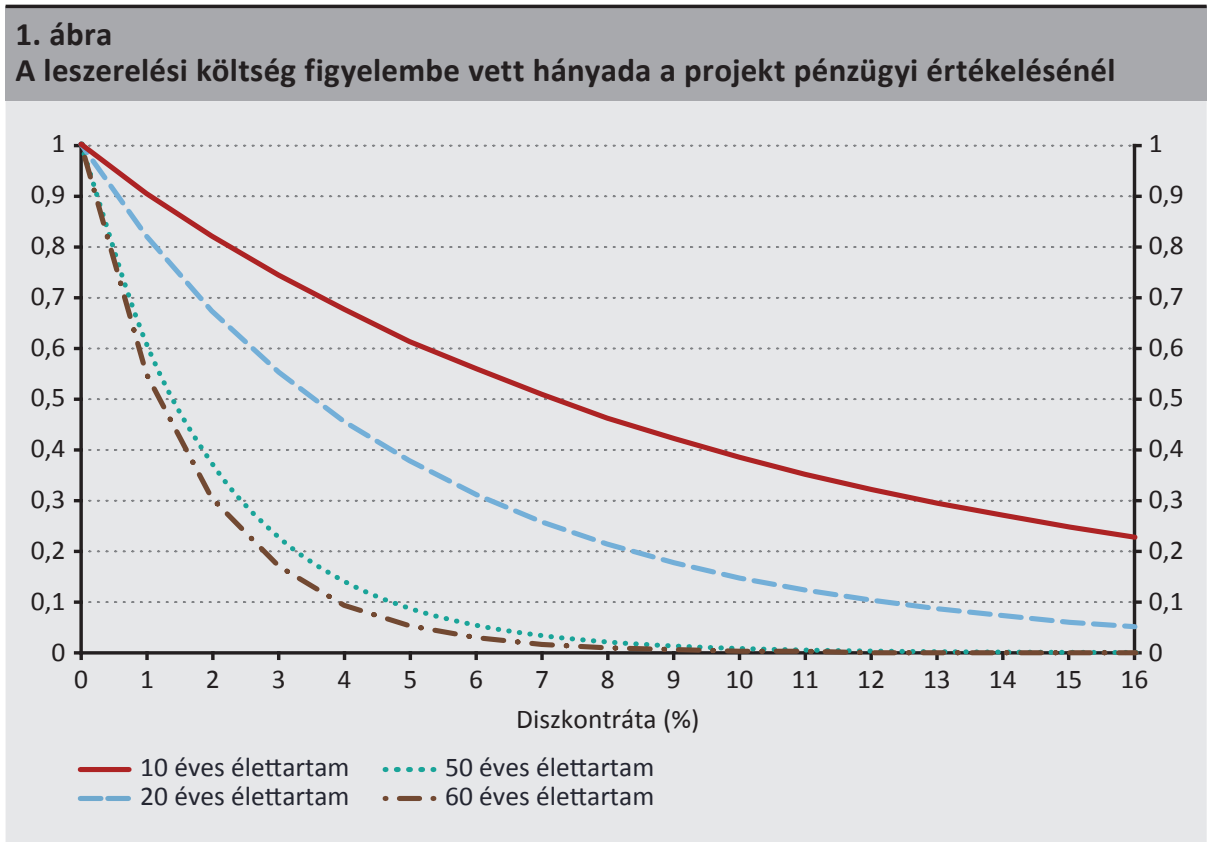


Ha egy projekt értékelése tízéves élettartamra szól, akkor a legfelső görbén látjuk, hogy 2 százalékos diszkontráta alkalmazásánál a leszerelési költségek 82 százalékát vesszük figyelembe a pénzügyi értékelésnél. (Ha ez az összeg 1 milliárd forint, akkor ennek a nettó jelenértéke 800 millió forint.) Ahogy növeljük az élettartamot és/vagy növeljük a diszkontrátát, úgy válik egyre jelentéktelenebbé a beruházási döntésnél figyelembe vett leszerelési költség. Sok olyan iparág van, ahol jelentős leszerelési költséggel kell számolni, mert pl. a beruházásnál használt gépek, területek, épületek másra nem használhatók és/vagy veszélyesek a környezetre (pl. bányák, erőmúvek, vegyi üzemek bezárására kerül sor). Ebben az esetben a hosszú távra, 50-60 évre tervezett élettartam már egy 4-5 százalékos diszkontrátával párosítva is azt jelenti, hogy a leszerelés terhét alig, vagy egyáltalán nem vesszük figyelembe a beruházási döntéseknél, azt teljes egészében a jövő generációra hárítjuk. Ebben az esetben összekapcsolódik a bizonytalanság és a jövő generációk terveinek ignorálása. Bizonytalanok vagyunk a jövőbeli költségek tekintetében, de ahelyett, hogy ezt bevallanánk, olyan látszólag csak „technikainak” tűnő módszert választunk, amely a jövőbeli eseményeket pénzügyileg súlytalanná teszi. Azok a döntéshozók, akik kimondják a végső szót, legyen szó gazdasági szakemberekről vagy a beruházást finanszírozó politikusokról, rendszerint nincsenek tudatában annak, hogy a beruházás gazdaságosságát kimondó ítéletet nagyban befolyásolja a diszkontráta mértékének megválasztása.

A távoli jövőben jelentkező pénzáramok diszkontálásakor a fenti ábrán bemutatott összefüggés mindig jelentkezik, függetlenül attól, hogy magán- vagy közösségi beruházásról van szó. A német atomerőmúvek magánberuházásban épültek, a magyar atomerőmű beruházója a magyar állam volt. A leszerelési költségek mindkét esetben jelentkeznek, s ezeknek a nagyságát szinte fel sem lehet becsülni, hiszen a nagy radioaktivitású hulladékokat akár több százezer évig is biztonságos helyen kell tárolni. Ha a tárolást nem is számoljuk, csak a leszerelés, ártalmatlanítás és lerakás közvetlen költségeit, akkor is olyan összegekről van szó, amelyeket nem az egyes (magán vagy állami) vállalatok, hanem a társadalom fog mindkét esetben megfizetni. A Német Szövetségi Köztársaság Parlamentje mellett múködő Tudományos Szakértői Bizottság szerint a leszerelés előzetesen becsült költségeit nem fogják fedezni a német energiavállalatok mérlegeiben elkülönített tartalékok, amelyek egyébként egyelöre csak ígérvényt jelentenek, és nem valósan elkülönített pénzösszegeket (BWE 2015). Ebből a példából is kitűnik, hogy az intertemporális, 40-50 éves, vagy még hosszabb időhorizontú döntések esetében magának a diszkontrátának ugyanolyan hatása van akkor is, ha közösségi, akkor is, ha privát beruházásról van szó. Mindkét esetben a kellően magas diszkontrátával a jövő generációkra hárítjuk a leszerelés terhét, miközben megvalósítunk olyan projekteket is, amelyeket nagyon alacsony, vagy akár zéró diszkontráta mellett pénzügyileg életképtelennek tartanánk. 


\section{Deskriptív és preskriptív eljárások a diszkontráta megállapítására}

Az optimális diszkontráta megállapítására alkalmazott eljárások eltérnek aszerint, hogy milyen projektről van szó. A magánberuházások és a társadalom által fontos, de a piaci keretfeltételek és megtérülési követelmények próbáján elbukó közösségi beruházások esetében is változatos módszereket találunk a diszkontráta megállapítására. Alapvetően két módszert különböztethetünk meg. Az első csoportba tartoznak azok a módszerek, amelyek valamilyen gazdasági folyamat megfigyelése alapján kalkulálják ki a diszkontrátát (deskriptív, pozitív módszerek), a második csoportban pedig kinyilvánított morális elvek irányítják a diszkontráta meghatározását (normatív, preskriptív módszerek).

\subsection{Az emberek diszkontálási szokásainak megfigyelése}

A viselkedési közgazdaságtan számtalan kísérletben állapította meg, hogy az emberek elsősorban a jelent preferálják, és nagyon erőteljesen diszkontálják a jövőben várható jutalmakat. Ez a viselkedés szinte valamennyi élő szervezet jellemzője, nem csak az emberi viselkedés meghatározó eleme. Az egyéni türelmetlenség ilyen magas fokának az is oka lehet, hogy nem lehetünk biztosak abban, hogy életben leszünk addig, amíg a jövőbeli hasznokat learathatjuk - vagy viselhetjük a jövőbeli költségeket (Lewandowsky et al. 2017). Ezt támasztja alá Trostel és Taylor (2001) elemzése is az USA háztartási panel (PSID) fogyasztási szokásainak adatai alapján. A szerzők arra jutottak, hogy a diszkontálási hajlandóság nem konstans az emberi élet különböző korszakaiban, s minél idősebb valaki (minél közelebb érzi magát a halálhoz), annál inkább hajlamos a jövő erőteljesebb diszkontálására.

Az emberek diszkontálási hajlama nem feltétlen lineáris, nem értékel minden jövőbeli eseményt, fogyasztási lehetőséget egyformán. A hiperbolikus diszkontálás koncepciója azt a megtakarításoknál, hitelfelvételnél, de akár sportnál vagy kábítószer-függőségnél is észlelt jelenséget írja le, hogy az emberek egy olyan, legjobban hiperbolikus görbével ábrázolható, jövőbeli értékelési sémát alkalmaznak, ami szerint türelmetlenek, ha a jelenről (vagyis rövid távról) és türelmesek, ha a jövőről van szó (v.ö. Rambaud - Torrecillas 2006).

\subsection{A tőkepiacok és a versenypiaci folyamatok megfigyelése alapján megállapított diszkontráta}

A privát beruházásoknál használt diszkontráta megállapításánál nagyon sok tényezőt vesznek figyelembe, így pl. a vállalati tőkeköltségeket mind a saját, mind az idegen tőkét tekintve (WACC), az adott projekt kockázatait, az inflációs hatásokat és egyéb, az iparágra jellemző szisztematikus kockázatokat. A vállalati gyakorlatban ezért a diszkontráta meghatározása (valójában becslése) viszonylag széles keretek között mozog, függ a vállalat nagyságától, tőkestruktúrájától, a befektetők által elvárt tőkejövedelmezőségtől, a rendelkezésre álló szabad pénzeszközeitől, sőt a me- 
nedzsment rátermettségétől, stratégiai rövidlátásától (Jagannathan et al. 2016), de attól is, hogy az adott országban melyek a szokásos eljárások, vagy éppen az adott döntéshozó mit gondol helyesnek (v.ö. Szücsné 2014).

\subsection{Társadalmi diszkontráta}

A társadalmi diszkontráta megállapítására azért van szükség, mert vannak olyan hosszú távú beruházások, amelyek fontosak a társadalom hosszú távú jóléte vagy különböző közjavak előállítása során. Ezek a szokásos, a privát beruházásokra megállapított diszkontrátával történő pénzügyi értékelés során negatív nettó jelenértéket produkálnak, noha a társadalmi nettó jelenértékük pozitív (Tabi 2012).

A társadalmi beruházások esetében elvégzett költség-haszon elemzésben alkalmazott diszkontráta megállapítására négy módszert szoktak alkalmazni.

- A társadalmi időpreferencia ráta (social time preference rate - STPR) azt mutatja meg, hogy a társadalom mekkora jövőbeli hozamért hajlandó elhalasztani a jelen fogyasztását.

- A társadalmi lehetöségköltség (social opportunity cost - SOC) számítása, ami a pénzpiacok költségeit tükrözi (Tabi 2012; Tabi - Csutora 2011), összehasonlítva azt a két állapotot, amikor a beruházásra szánt tőkét a privát, illetve az állami szektorban használják fel.

- A súlyozott átlaggal (weighted average method - WAM) azoknak a projekteknek a diszkontrátáját lehet kiszámolni, ahol mind a magán-, mind az állami szektor részt vesz. Ez a társadalmi időpreferencia ráta és a társadalmi lehetőségköltség súlyozott átlaga.

- A tőke árnyékára (shadow price of capital - SPC) az erőforrás költségének teljes, az externális hatásokat is tartalmazó ára. Ekkor azt a hasznot próbálják beárazni, amit az adott beruházás az egész társadalomnak hoz, pl. valamilyen szennyezés, árvíz stb. elkerülésével (Liu 2011).

Ezek közül a módszerek közül a tőke árnyékára és a társadalmi lehetőségköltség egyértelműen a deskriptív módszerek közé tartozik. A társadalmi időpreferencia ráta meghatározására normatív kísérleteket figyelhetünk meg, ahogy azt a Ramsey-formula tárgyalásánál bemutatjuk.

\subsection{Szakértői megkérdezések}

Weitzman $(1998,2001)$ a társadalmilag hasznos projektek diszkontálásával kapcsolatos ellentmondások feloldására dolgozta ki a később gamma diszkontálásként említett módszert, ami több ország társadalmi projektértékelésében is teret nyert. A távoli jövőben minden, a diszkontrátát befolyásoló tényező, így a növekedési ráta mértéke is bizonytalan. Minél távolabbi a jövő, annál kisebb diszkontrátát java- 
sol Weitzman, vagyis a diszkontráta nem konstans, hanem időszakonként változik. A csökkenő diszkontrátával (DDR: declining discount rate) valójában a diszkontálás matematikáját próbálják kiigazítani. A hosszabb időtávokra alkalmazott alacsonyabb, vagy akár nullához közeledő diszkontálással elkerülhető, hogy a jövőbeni értékek nagyon kicsivé, s ezáltal jelentéktelenné váljanak. A diszkontráta mértékének meghatározását Weitzman szakértői megkérdezéssel alapozta meg (Freeman - Groom 2015).

\subsection{A deskriptív diszkontráta megállapítására alkalmazott eljárások etikai értékelése}

Teljesen nyilvánvaló, hogy annak megállapítása, milyen súllyal vesszük figyelembe a cselekedeteink hatását a jövő generációkra, alapvetően etikai kérdés. A deskriptív módszereket alkalmazók látszólag megkerülik ezt a problémát, de már ezzel is kinyilvánítják, hogy szerintük a status quo az, amit preferálnak, vagyis az a jó, ami valamiképpen megfelel a múltbeli trendekből levezethető jelennek és jövőnek. Eszerint a diszkontrátát valamiféleképpen a tőkepiacokon aktuálisan megfigyelt, vagy a múltbeli trendekhez kötődő, elvárt, jövőbeli kamatszinthez, megtérülési elvárásokhoz, valamilyen piaci árak alapján kiszámolt értékhez, esetleg a humán ágensek diszkontálási mintáihoz kell igazítani.

A deskriptív állásponttal szemben több érv is felhozható. Az első ellenérv rámutat a deskriptív módszer episztemológiai korlátaira - hogyan határozzuk meg „normatív módon" a deskriptív diszkontráta megállapításának módszerét, ha még maguk a gazdasági élet szereplői sem tudják, mi lenne az „optimális”, hiszen az valójában még ugyanabban a piaci környezetben is vállalatról vállalatra, projektről projektre változik (Szücsné 2014; Jagannathan et al. 2016).

Ha a versenypiaci, rövid időhorizontú befektetésekre alkalmazott diszkontálási gyakorlat alapján határozzuk meg a társadalmi diszkontrátát, akkor ez további módszertani kérdéseket is felvet. Azok a modellek, amelyek alapján sor kerül a deskriptív diszkontráta megállapítására a valóságos üzleti-társadalmi folyamatokat túlságosan is leegyszerúsítik. Ezeket az eredményeket pl. Nagy-Britanniában vagy Franciaországban normatív módon használják a valóságos beruházási számításoknál (HM Treasury 2003). A leegyszerüsítés legvitathatóbb része az, hogy sokszor nem tesznek különbséget a magánjavakba és a közjavakba történő beruházások között. A modellek így hallgatólagosan azzal a feltételezéssel élnek, hogy az erre szánt erőforrások egymással kölcsönösen kicserélhetők (pl. Weitzman 2012; Groom et al. 2007). Ezzel szemben a közjavakba és a magánjavakba történő beruházások nem vizsgálhatók ugyanolyan gazdaságossági kritériumok alapján, mert a közjavakba történő beruházások által keletkezett „haszon” jó része nem mérheto, s azzal a kockázatkerülő magatartással van összefüggésben, aminek hiánya akár az egész társadalom pusztulásához vezethet. A levegőszennyezés csökkentésére tett erőfeszítések hasznát ugyan megpróbálhatjuk mérni az így elkerült betegségek kezelésének a költségeivel, de akkor nem vettük figyelembe azoknak a jobb közérzetét 
„életminőségét”, akik közvetlenül nem betegednek meg, vagy azokat az élőhelyeket, amelyek nem pusztulnak el pl. a savas esők miatt. A gátakat akkor is az elmúlt száz év legnagyobb vízállásához kell igazítani, ha a jövőben csökken a csapadék, és csak kicsi a valószínűsége egy nagyon nagy árvíznek. A magánjavak előállításába fektetett pénzáramok által keletkezett jövőbeli „haszon”, ami a monetárisan jelentkező bevételekkel mérhető, nem hasonlítható össze a közjavak előállítására fordított beruházásokból keletkező, gyakran generációkon átívelően jelentkező „,hasznossággal”. A fenti racionálisnak tűnő érvek ellenére a közjavak és a magánjavak elkülönítése egyre nehezebbé válik a gyakorlatban. A klasszikus közjószágként felsorolt oktatás, egészségügy, védelem ma már egyre inkább átsorolódik a magánjószágok közé. Az, hogy egy adott jószág, pl. a tiszta levegő közjószág vagy magánjószág-e, nagy részben a társadalom megegyezésén alapul (Malkin - Vildavsky 1991). Amíg Kínában csak a középosztály engedheti meg a tiszta levegőt Pekingben a magánlakásokban felszerelt légtisztító berendezések müködtetésével, ez az Európai Unióban - ma még - alapvető emberi jog, aminek megsértését szankcionálják.

Ha a humán ágensek diszkontálási szokásait szeretnénk alapul venni, akkor nemcsak az kérdéses, hogy kinek a diszkontálási szokásait vesszük figyelembe, és hogyan jutunk az adatokhoz, illetve milyen elvek alapján következtetünk egy diszkontrátára, hanem fel kell vetni a racionalitás problémáját is. Nagyon sok kísérlettel vizsgálták a hiperbolikus diszkontálási szokásokat, amikor az emberek a saját életükkel kapcsolatban hoznak döntéseket. Ezek a döntések azonban nemcsak az egyes emberek szintjén különböznek egymástól, hanem az időben sem konzisztensek, hiszen minden újabb időpillanatban változhat a diszkontálás referenciapontja. Ezért elfogadhatónak túnik az a következtetés, hogy az így kapott eredmények nem szolgálhatnak a racionális döntések módszertani alapjául (v.ö. Rambaud - Torrecillas 2006). Másrészt etikailag sem elfogadható, ha egy olyan módszert alkalmazunk a jelen és jövő társadalmának befolyásolására, amely az egyéni önzést helyezi a középpontba a társadalom érdekeivel szemben. Ez utóbbi kijelentés arra az etikai maximára épül, miszerint a gazdaságnak a társadalmat kell szolgálnia (Odum 1983; Tainter 1988), s a technológiai beruházási döntések során a legfontosabb az emberi faj hosszú távú fennmaradása (Jonas 1984).

A deskriptív ráta "normatív alkalmazása” már önmagában is komoly filozófiai problémát vet fel, amivel Hume törvénye foglalkozik. Hume (1739) ugyanis megjegyzi, hogy abból levezetni, hogy „mi van”, azt, hogy „minek kellene lennie”, valójában módszertani hiba, s az így kapott morális parancsoknak nincs megfelelö logikai alapjuk. Hume törvénye az etikai vizsgálódások módszertani alapjául is szolgál. Ebből adódóan nem csak episztemológiai korlátai vannak a deskriptív diszkontálás alkalmazásának, etikai okokból sem tehetjük meg, hogy a valamilyen partikuláris megfigyelés alapján aktuálisan posztulált diszkontráta alkalmazását tesszük kötelezővé a hosszú távú, beláthatatlan jövőre kiható projektekben. 


\subsection{Etikai megfontolások alapján megállapított diszkontráta}

Az etikai keretrendszerek aszerint különböznek, hogy milyen döntési szabályokat alkalmaznak annak megállapítására, hogy mi a jó és mi a rossz. A két legfontosabb klasszikus etikai irányzat a kötelességetika és a következményetika. Mind a két etika középpontjában az emberi cselekvés és annak értékelése áll. A kötelességetika esetében a hangsúly a cselekvő ágens intencióján (szándékán) van, hiszen a döntés pillanatában nem tudjuk, hogy mi lesz a cselekvés következménye. Az intertemporális döntések esetében a kötelességetika nem nyújt megfelelő gyakorlati támpontot az értékelésre. A kötelességetika döntési szabálya az általánosítás. A jó és a rossz megítélése aszerint történik, hogy van-e olyan általánosítható, mindenkire vonatkoztatható erkölcsi parancs (maxima), amit alkalmazhatunk az adott szituációban (Kant 1995). A diszkontálás esetében egy ilyen, minden körülmények között alkalmazandó, feltétlenül betartandó norma (kategorikus imperatívusz) nehezen képzelhető el. A deontológia elveit kutató filozófusok ugyan foglalkoznak azzal, hogy milyen kötelességünk merül fel a többi élőlény vagy a jövőben élő emberekkel szemben, de ez elsősorban egy statikus filozófia, ami nem tudja kezelni a hosszú időhorizontú, esetlegesen több generációt is érintő eseményeket, hiszen a döntés pillanatára fókuszál (Hampicke 2011).

A következményetika szerint viszont nem az intenció (szándék), hanem a cselekmény következménye az, amiről etikai ítéletet hozhatunk, vagyis kimondhatjuk róla, hogy jó vagy rossz. Sokféle viszonyítási alapot adhatunk meg a következményetikában, mérhetjük a következményeket aszerint, hogy nő, vagy csökken a társadalom vagy az érintettek szabadsága (Gaus 2012). Vizsgálhatjuk azt, hogyan hat az adott cselekvés az egyén, az érintettek, az egész társadalom, vagy minden élő és megszületendő ember boldogságára (Sinnot-Armstrong 2015). Az etikai keretrendszerek közül nem véletlen, hogy a következményetika fogalomrendszerének segítségével vizsgálhatjuk meg, hogyan hatnak a mai döntéseink a jövő generációira. Az etikai ítéletet arról, hogy a diszkontálás, illetve a diszkontráta megválasztása rossz vagy jó, aszerint mondhatjuk ki, hogy a mai diszkontálási módszerekkel életképesnek ítélt beruházásoknak mi a következménye a jövőben, vagyis a mai és a jövőbeli generációk között hogyan osztják meg a terheket és a hasznokat (Broome 1994; Sen 1973).

A diszkontálással a következményetikához tartozó utilitarizmus irányzatai közül a klasszikus kardinális utilitarizmus és diszkontált utilitarizmus foglalkozik (Gollier 2011; Greaves 2017). A kardinális utilitarizmus feltételezi, hogy az öröm, illetve a közgazdasági értelemben ennek megfeleltetett hasznosság mérhető és kifejezhető az egyéni preferenciákban (pl. Jevons 1911). Harsányi (1955) kifejti, hogy az egyes individuumok képesek arra, hogy összehasonlítsák egymás között is az egyes választásokkal elérhető hasznosságot, s ennek az összehasonlításnak az alapja nem valamiféle pszichológiai alapon létrejövő szubjektív érzés, hanem a tényeken alapuló induktív érvelés. A diszkontált utilitarizmus és különböző irányzatai már 
többé-kevésbé figyelembe veszik a különböző generációk közötti érdekellentéteket (Greaves 2017), ennek egyik legelső képviselője Ramsey.

A diszkontálással foglalkozó utilitárius álláspontokból kiindulva két, egymásnak teljesen ellentmondó eredményre juthatunk: a klasszikus kardinális utilitarizmus alapján nem szabad diszkontálni, vagyis pl. a klímaváltozás kontextusában le kell mondanunk a jelen fogyasztásunkról azért, hogy enyhítsük a jövőbeli generációk terheit. A diszkontált utilitarizmus szerint a diszkontálás morális kötelességünk, $s$ alig kell törődnünk azzal, hogy mi történik a jövőben, különösen a távoli jövőben az utódainkkal (Greaves 2017). A következőkben a Ramsey-formula elemzésével mutatjuk be, hogy milyen megfontolások vezethetnek ehhez a két ellentétes etikai állásponthoz.

\section{A Ramsey-formula}

A hosszú távra, vagyis a beláthatatlan jövőre vonatkozó diszkontálással kapcsolatos, a 60-as évek végétől fogva egyre szélesebb hullámokat vert diskurzus kiindulópontja Ramsey 1928-as tanulmánya a megtakarítások matematikai elméletéről (a vita összefoglalását lásd pl. Arrow et al. 2012; Gollier 2011). Ennek a tanulmánynak a fókuszában az a kérdés áll, hogy mennyit kell ahhoz megtakarítania egy társadalomnak, hogy nagyon hosszú időre - „örökre” - maximalizálja a jólétét. Ramsey modellje egy zárt társadalomból indul ki, amit először egyetlen örök életű fogyasztó alkot, aki maga rendelkezik a termelési tényezőkkel, maga is fogyasztja el a megtermelt javakat, s annyit szeretne megtakarítani, hogy mind a jelenben, mind a jövőben maximális hasznosságot érjen el. Ahhoz, hogy ezt meg tudja valósítani, a határhasznosságot állandó szinten kell tartania, vagyis minden egyes új egységnyi termék elfogyasztása esetén ugyanakkora hasznosságot kell tulajdonítania a fogyasztásnak. Ramsey egyik alapfeltételezése éppen ezért az, hogy a fogyasztás során a határhasznosság nem nő végtelenségig, hanem egy bizonyos határértékhez (az elérhető legnagyobb boldogsághoz) konvergál. Később Ramsey feloldja az egyetlen fogyasztó koncepcióját, s ezt az egymás után következő generációkban testesíti meg, amikor az egyes egyének a saját, illetve örököseik hasznával vannak elfoglalva.

A modellben Ramsey megkülönbözteti a hasznosság diszkontálását a pénzáramok diszkontálásától. Míg az utóbbinál a diszkontráta egyenlő a kamattal, a hasznosság esetében különböző embereknek különböző elképzelésük lehet a hasznosságról, s ez a heterogenitás a hasznosságra alkalmazott diszkontráta nagyságában jelenik meg. Ramsey egy, alapvetően két csoportra bomló társadalomról beszél, ahol az emberek, pontosabban az örökké élő családok aszerint lesznek gazdagok, vagy szegények, hogy mennyire türelmesek, vagyis mennyiben képesek lemondani a jelen fogyasztásról azért, hogy az így nyert megtakarításokat befektessék. 
Ramsey modelljéből a pénzáramok (és nem az individuális hasznosságok) diszkontálására alkalmazott ráta, vagyis a kívánatos kamatszint a következő egyenletből vezethető le, amit Ramsey-formulának nevezünk:

$$
r=\delta+\eta g
$$

Ahol az adott időpillanatban a rátát a következő három tényező határozza meg:

- $\delta$ = tiszta társadalmi időpreferencia ráta

- $\eta$ = fogyasztás marginális hasznosságának rugalmassága

- g = egy főre jutó fogyasztás növekedési üteme.

Az így meghatározott $r$ nagysága azt a kamatszintet adja meg, amelyet a megtakarításokból finanszírozott beruházásoktól várunk el, s amely biztosítja a társadalmi jólét megőrzését az intertemporális döntések esetében. Ebből adódóan ahhoz, hogy maximalizáljuk a jelen és a jövő társadalmában a hasznosságot, ugyanezt az értéket kell alkalmaznunk diszkontrátaként is (Greaves 2017).

A Ramsey-formulát gyakran használják azoknak a beruházásoknak az értékelésénél, amelyeket a társadalom kénytelen megtenni, hogy a jólétét a jövőben is megőrizze, de amelyek a piaci feltételek között nem térülnek meg. Így a Ramsey-formula megalapozza a társadalmi diszkontráta megállapításának már említett, széleskörűen alkalmazott módszerét. A társadalmi időpreferencia rátának átnevezett $r$ azt mutatja meg, hogy mennyiért hajlandó lemondani a jelen társadalom azért, hogy biztosítsa a következő generációk fogyasztását (Tabi - Csutora 2011).

A Ramsey-formula egyes paramétereinek meghatározása elárulja, hogy kinek milyen elképzelései vannak a jövőről, és kinek az érdekeit veszik figyelembe az intertemporális döntéseknél.

\subsection{A tiszta társadalmi időpreferencia}

A tiszta társadalmi időpreferencia az a paraméter, amellyel kapcsolatban a legkülönbözőbb véleményekkel találkozunk. Ezt a paramétert ma úgy interpretálják, mint az egymás utáni generációk „türelmetlenségének mérőszámát” (Tabi-Csutora 2011), amely azt mutatja meg, hogy milyen mértékben vagyunk hajlandók lemondani a jelen fogyasztásról a jövő generáció javára. Ezzel szemben Fisher (1930) szerint a társadalom és/vagy az individuum türelmetlenségét a teljes Ramsey-formula fejezi ki. A tiszta társadalmi időpreferenciát kombinálni kell az elvárt egy főre eső növekedéssel, ami a klasszikus elmélet szerint a fogyasztás határhasznosságának csökkenéséhez vezet.

A tiszta társadalmi időpreferencia fentebb idézett értelmezése elhalványítja Ramsey eredeti definícióját. Nála a tiszta társadalmi időpreferencia valójában a hasznosság 
függvénye, s nem a pénzáramoké (Ramsey 1928:288). Ez a paraméter Ramsey-nél azért nulla, mert nem hasonlíthatók össze egymással a különböző időben élő emberek hasznosságai, illetve az egyes egyének kontextusában a ma érzett hasznosság a később érzett hasznossággal. Éppen ezért etikailag nem elfogadható, ha bármelyik generáció hasznosságát előnyben részesítjük a másikkal szemben.

Amíg Ramsey-nél egy ismeretelméleti előfeltevés alapozza meg azt az álláspontot, miszerint a tiszta társadalmi időpreferencia ráta értéke nulla, a későbbi szerzők (pl. Cline 1992; Dasgupta 2008, Gollier 2011) ezt már a pártatlansággal és a generációk egyenlőségével magyarázzák, hiszen nem különböztethetjük meg a hasznosságot attól függően, hogy mikor melyik generáció élvezi azt. Gondoljunk olyan közjószágok által nyújtott hasznosságra, mint a tiszta levegő, az erdő vagy a szennyezéstől mentes folyó. Meg kell említeni, hogy Stern (2007) szerint sem értékelhetjük a jövő generációk jólétét kevesebbre, mint a sajátunkat. A nulla társadalmi időpreferencia ráta így oda vezet, hogy egyedül a növekedés és a fogyasztás határhaszna befolyásolja a diszkontráta nagyságát.

Milyen érvek szólhatnak amellett, hogy a tiszta társadalmi időpreferencia ráta pozitív legyen, vagyis többre értékeljük a mai hasznosságot, mint a jövőbelit? Vagyis mi indokolhatja, hogy ne legyünk pártatlanok az intertemporális döntések esetén? A legkézenfekvőbb érv az, hogy meghalunk, s mivel ezzel fokozódik a lehetősége annak, hogy nem részesülünk a megtakarításaink következtében létrejövő jövőbeli hasznosságból, ezért mégis csak előnyben kell részesítenünk a saját generációnkat. Ez az érv alátámasztható az egyes egyének közötti hasznosság maximalizálásának elve alapján. Az életesélyekkel korrigált tiszta időpreferencia ráta a halálozási arányszámmal növeli meg a paraméter értékét. Ha az életesélyek romlanak, az megemeli az időpreferencia értékét, ha javulnak, az csökkenti (Pearce - Ulph 1995).

A második érv szerint ahhoz, hogy biztosítsuk a következő generációk jólétét, óriási áldozatokat kell hoznunk. Arrow (1999) szerint minden generáció önző, s éppen ezért nem várhatjuk el tőle, hogy a következő (szintén önző) generáció javára úgy mondjon le a jelenbeli fogyasztásról, hogy maximalizálja valamennyi utána következő generáció hasznosságát. Ez ugyan nem zárja ki a következő generációk érdekeinek figyelembe vételét, de a nullánál nagyobb tiszta időpreferencia rátát eredményez. Ha egy generációkon átívelő hosszú távon hasznot hajtó beruházásra gondolunk, mint amilyen pl. Arrow (1999) szerint a Hoover gát, akkor azok a generációk, amelyek élvezik ennek a beruházásnak a hasznát, előnybe kerülnek annak a generációnak a tagjaival szemben, akik megtakarításaikból finanszírozták a beruházást. Azok, akik később élvezik a gát által nyújtott előnyöket, akár csökkenthetik is a saját megtakarításuk mértékét, így előnybe kerülnek az előző és a következő generációkkal szemben. Ez a gondolatmenet összhangban van az utilitarista felfogással, hiszen az adott keretek között az egyes generációkkal szemben alkalmazott retorzió (a diszkontálás formájában) kísérletet tesz arra, hogy csökkentse az ön- 
zésből fakadó előnyüket, és így több ember között teríti szét, egyenletesebbé teszi a hasznosság eloszlását.

\subsection{A fogyasztás határhasznosságának rugalmassága}

A fogyasztás határhasznosságának rugalmassága azt fejezi ki, hogy a saját jólétünktől függően ítéljük meg minden jövőbeli pótlólagos egységnyi fogyasztás hasznát. Pénzáramokban kifejezve egy gazdag ember számára sokkal kevesebbet ér, ha kap még 100 forintot, mint egy szegény ember számára. Miután ez egy arányszám, ha a határhasznosság rugalmassága 1, akkor ugyanakkora haszna keletkezik egy százaléknyi plusz fogyasztás esetén a szegény és a gazdag embernek is. (Abszolút értékben kifejezve persze eltérnek az értékek, egy szegény embernek, akinek 100 forintja van, ugyanakkora hasznosságot jelent minden pótlólagos 1 forintnyi fogyasztás, mint egy 1000 forinttal rendelkező gazdag embernek minden plusz 10 forintnyi fogyasztás.) Ha ez az arányszám nagyobb, mint egy, akkor ez azt fejezi ki, hogy a gazdag ember számára kevesebb hasznot hoz, ha ugyanakkora százalékkal növekszik a fogyasztása, mint a szegény emberé. Ez az összefüggés Gossen törvénye a csökkenő határhaszonról, valójában egy axiomatikus keretfeltétel, amit olyan analógiákkal szoktak szemléltetni, hogy ha van már egy házam/almám, autóm stb., akkor a jövőben sokkal kevesebb hasznom van abból, ha kapok még egyet, mint ha nincs, így nem valószínü, hogy ma érdemes azért megtakarítanom, hogy annak a hasznát a jövőben élvezzem. Ez az axióma plauzibilisnek tűnik a fogyasztási cikkeket tekintve egy generáción belül, vagyis pl. egy individuumnak a saját jövőjét meghatározó döntéseit tekintve.

Az egynél nagyobb érték a fogyasztás határhasznosságával kapcsolatban azt jelenti, hogy - amennyiben a többi tényező változatlan és a növekedés pozitív - a diszkontráta magasabb lesz. Így ez a paraméter felfogható a jelen és a jövő fogyasztás közötti egyenlő elosztás biztosítékaként is, ami az intertemporális „egyenlőtlenségtől történő idegenkedés" (inequality aversion) mértékét mutatja meg (Gollier-Hammit 2014). Arrow et al. (2004) szerint ez a paraméter biztosítja a generációk közötti igazságosságot.

Vannak olyan intertemporális döntések, amelyek meghatározzák pl. a természet jövőbeli állapotát, csökkentik a klímaváltozás hatását. Vajon miért jelentene kisebb hasznot egy gazdag, mint egy szegény ember számára az, ha sikerülne megmenteni bizonyos állat- és növényfajokat, pl. a jegesmedvét a kihalástól (Frederick 2006)? A gazdag emberek általában sokkal nagyobb hajlandóságot mutatnak az ilyen projektek támogatására, mint a szegények. Ebből az is következne a fenti gondolatmenet analógiája alapján, hogy számukra nagyobb hasznosságot jelent, ha a természeti javakból a jövőben is részesülhetnek, mint a szegény emberek számára (Revesz - Shahabian 2011). Így, ha a jelen fogyasztást preferáljuk ahelyett, hogy befektetnénk olyan projektekbe, amelyekkel a természet által nyújtott szolgáltatásokat megőriznénk, akkor elképzelhető, hogy a szűkössé váló, eltűnő természetet 
a jövő generációja sokkal jobban fogja értékelni, mint ahogy azt a jelenben tesszük, ezért az ilyen projektek esetében a paraméternek pozitiv egy főre eső növekedés esetében kisebbnek kell lennie egynél, hogy csökkentse a diszkontráta értékét.

\subsection{Az egy före jutó fogyasztás növekedési üteme}

A Ramsey-formula látszólag legegzaktabb paramétere az egy före jutó fogyasztás növekedési üteme. Ha eltekintünk a többi paramétertől, vagyis a tiszta időpreferencia rátának az értéke nulla, és a fogyasztás határhasznosságának rugalmassága egy, akkor egyedül a növekedési ütem az, ami meghatározza a diszkontrátát.

A közgazdászok általában azt feltételezik, hogy a növekedési ütem hosszú távon pozitív. A növekedés forrása a tőke felhalmozódása és a technológiai változás (Pearce - Ulph 1995). Ezt az értéket pl. a retrospektív, 100-180 évre visszamenő adatok alapján Nagy-Britanniára 1,3-1,6-ra becsülik (OXERA 2002). Amennyiben elfogadjuk ezt az értéket a jövőbeli hosszú távú növekedési ütemmel kapcsolatban is, akkor ennek alapján könnyú megindokolni a diszkontált utilitarizmust. Miután a célunk az, hogy biztosítsuk a beruházások hasznának generációk közötti optimális - vagyis legegyenletesebb - elosztását, akkor mindenképpen diszkontálnunk kell. Diszkontálás nélkül ugyanis a jelen generációk lemondanak a fogyasztásukról azért, hogy a gazdaság növekedése által gazdagabbá váló jövő generációk még gazdagabbak legyenek. Ahogy Baumol (1968) megjegyzi, ez egy "fordított Robin Hood" intézkedés, hiszen 100 év múlva az átlagos fejenkénti jövedelem a mostaninak (reálértékben mérve) a sokszorosa lehet, s miért mondjunk le a jövedelmünk egy részéről azért, hogy azt odaadjuk a nálunk módosabbaknak.

Amennyiben a növekedési ütem nulla, akkor viszont nincs jogunk arra, hogy diszkontáljunk, hiszen a diszkontálással szegényebbé tesszük a jövő generációit. Broome (1994), a kardinális utilitarizmus híve szerint a diszkontálás különösen a klímaváltozás kontextusában nem igazolható, mert a klímaváltozás hatásait leginkább a szegény országok fogják megérezni. Azok, akik hajlamosabbak ma befektetni az üvegházhatású gázok kibocsátásnak a csökkentésébe, a gazdag, iparilag fejlett országok, míg azok a szegény, fejletlen országok, amelyek leginkább meg fogják érezni a klímaváltozás hatását, még a jövőben is szegényebbek lesznek, mint a mai fejlett országok.

A két álláspont közötti vita (v.ö. pl. Sen 1973 és Pearce - Ulph 1995) nem az egyenlőségen és pártatlanságon alapuló utilitarista elvek megkérdőjelezéséből adódik, hanem a szerzők világról alkotott modelljének egymástól eltérő konstrukciójából. Míg Sen (1973) számára az egyes generációk homogének, addig Broome (1994) a generációkon átívelő diszkontálás kérdéskörét kibővíti a generációkon belüli egyenlőtlenségekkel. Ha mind a jelen, mind a jövő generációja szegényekből és gazdagokból áll, akkor valóban kérdéses, hogy hogyan viszonyul a jelen gazdagsága a jövő szegénységéhez. Ez a probléma még akkor is jelentkezik, ha a gazdasági 
növekedés pozitív. Ha jelentős beruházásokat teszünk, amelyek a jövő generációt tehermentesítik a klímaváltozás hatásaitól, akkor két lehetőségünk van: az ahhoz felhasznált forrásokat vagy a szegényektől, vagy a gazdagoktól vonjuk el. Amennyiben a gazdagoktól, akkor érvényes lehet Broome (1994) érvelése. De ha ezeknek a beruházásoknak az az ára, hogy kevesebbet költünk a generációkon belüli egyenlőtlenségek felszámolására mind az egyes országokban, mind a fejlett országokba irányuló beruházások, segélyek, csökkentése miatt, akkor érvényessé válik a fordított Robin Hoodra történő hivatkozás. A jövő generációkban a szegények ugyanis azáltal lesznek kevésbé szegények, hogy kizsákmányoljuk a jelen generációk kevésbé jómódú tagjait.

Ha az egy före jutó fogyasztás növekedési üteme negatív, akkor viszont az az érdekes helyzet áll elő, hogy negatívvá válik a diszkontráta. Ezzel a lehetőséggel az irodalomban csak mellékesen foglalkoznak. Weitzman (2009) szerint azokban az esetekben, amikor nagyon nagy a kockázata egy közelgő katasztrófának, indokolt a jelen minden erőforrását arra fordítani, hogy ezt elhárítsák. Abban a modellben, amellyel ezt a tézist bizonyítja, a Föld emelkedő hőmérsékletének függvényében vizsgálja a fogyasztást. Ha megvizsgáljuk azt a hipotetikus helyzetet, amikor a végtelenül magas hőmérséklet miatt minimálisra csökken a fogyasztás, a negatív diszkontrátának is a végtelen felé kell tartania.

Az, hogy a GDP megfelelő mérőszáma-e a hosszú távú növekedésnek vagy a „társadalmi haszonnak", ha már a boldogságról rég nem is beszélünk, meglehetősen nagy vita tárgya. A klímaváltozás során egyre gyakoribbá váló extrém időjárási események, katasztrófák, áradások, erdőtüzek és a mezőgazdasági termésátlagok növekedési rátájának hosszú távon megfigyelhető világméretű és a hőmérséklet emelkedésével járó drámai mértékű csökkenése (Ray et al. 2013; Hatfield 2016) arra utal, hogy a közgazdászok folyamatos gazdasági és technológiai növekedésbe vetett hite előbb-utóbb beleütközik a természeti korlátokba. Amíg az elmúlt időszakban a monokultúrára, vegyszerezésre, genetikailag módosított terményekre és a természetet egyre kisebb fragmentált területekre visszaszorító mezőgazdasági technológiák hozzájárultak a GDP növekedéséhez, 1998 és 2013 között jelentősen, mintegy 20 százalékkal csökkent a termőképessége ezeknek a területeknek (GLO 2017). Az urbanizáció, a földhasználat változása s közben a GDP növekedés fetisizálása oda vezethet, hogy már nem lesz mit mérnie a jövő generációinak.

\section{Az utilitarista diszkontálás értékelése}

Noha látszólag a kardinális és a diszkontált utilitarizmus kibékíthetetlen ellentétben van egymással, valójában ez az ellentét a jövővel kapcsolatos eltérő várakozásokkal és a gazdasági szereplőkkel kapcsolatos sokszor ellentétes feltételezésekkel függ össze. A modellek alapfeltételezései közé tartozik a racionális, haszonmaximalizáló 
ágens, aki vagy örökéletű, vagy halandó. Ha halandó ágensekről van szó, akkor azok egymás utáni vagy egymást átfedő generációkba tömörülnek, amelyek vagy homogének a tőke eloszlását és a fogyasztást tekintve, vagy szegényre és gazdagra oszthatók.

A normatív álláspont elutasítja azt, hogy a generációk között különbséget tegyünk, vagyis preferáljuk a jelent a jövővel szemben (kardinális utilitarizmus) vagy a jövőt a jelennel szemben (diszkontált utilitarizmus). Ugyanígy kétségbe vonható ebből az álláspontból kiindulva a fogyasztás határhasznának csökkenése akkor, amikor nem a magánjószágok fogyasztásáról van szó, hanem a közjószágok vagy a természet, a környezet értékelésére kerül sor. A „legnagyobb boldogság” koncepcióját a diszkontálással foglalkozó utilitarista irodalomban általában a „hasznossággal” azonosítják. Ez a helyettesítés lényeges ugrást jelent egy abszolút, numerikusan nem mérhető boldogságfogalom és egy különböző módszerekkel legalább elvben kvantifikálható hasznosság-elképzelés között. A boldogságot (amit Ramsey a tökéletes, ám soha el nem érhető boldogságként („,bliss”) írt le) azonosítani a fogyasztás során elérhető hasznossággal, alapvető logikai hiba. Ugyanilyen logikai hiba összekeverni a természet által nyújtott szolgáltatások „hasznosságát” a fogyasztás hasznával.

Összefoglalásként elmondhatjuk, hogy az utilitarista etikai elemzés látszólag ellentmondásos eredményei a hasznosság különböző felfogásából, és/vagy a diszkonttényezőre ható különböző paraméterek, elsősorban a jövőbeni növekedési ráta eltérő becsléséből adódnak.

\subsection{Hogyan diszkontáljunk?}

A társadalom számára fontos beruházásoknál alkalmazott diszkontrátára igen változatos értékeket határoznak meg a világban. Az USA-ban ma a 3 és 7 százalékos diszkontráta is érvényben van az állami projektek esetében (CEAl 2017), Norvégiában 2,5 százalék a kockázatmentes projektekre, ami 41 év múlva 1 százalékra csökken, Hollandiában a kockázatmentes projektek esetében 0 százalék a diszkontráta, ezeket adott esetben kockázati prémiummal korrigálják (Groom 2017). A fejlődő országokban az alkalmazott diszkontráta ennél sokkal magasabb, akár 10-12 százalék is lehet, Szerbiában pl. 10 százalék (Djukic et al 2016). A változatos értékeket hol deskriptív, hol preskriptív alapon határozzák meg, hol pedig egyszerűen a politikai döntésekhez igazítják az adott projekt létesítését lehetővé tevő diszkontráta mértékét (Groom 2017).

A diszkontálási módszereket meghatározó eljárásokat és filozófiákat áttekintve azt állapíthatjuk meg, hogy sem az utilitarista normatív diszkontálás, sem a megfigyeléseken alapuló deskriptív diszkontálás (vagy a kettő valamilyen kombinációja) nem oldja meg az intertemporális projekteknél alkalmazandó diszkontrátával kapcsolatos etikai problémákat, s nem ad követhető útmutatást arra, hogy végül is mi legyen a diszkontráta. Az utilitarista diszkontálás csődje azonban nem jelenti azt, hogy 
le kellene mondanunk az etikai dimenzióról. Ha a diszkontálás meghatározására szolgáló modell keretfeltételeit alakító etikai referenciapontként nem az egyént vagy az egyéni érdekek aggregációjaként felfogott generációkat, hanem az emberi társadalmakat, vagy akár az egész emberiséget választjuk, akkor talán egy olyan megközelítéshez jutunk, amivel elkerülhetők a tanulmányban bemutatott modellek ellentmondásai. Azok az esetek, amikor a társadalmi diszkontráta alkalmazásáról kell döntenünk, rendszerint hosszú távú, az egész társadalom, vagy akár az egész emberiség számára fontos vállalkozások. Ide kell sorolnunk azokat a beruházásokat is, amelyek ugyan a magánszektor jóvoltából jönnek létre, de a jövőben jelentősen megterhelik a környezetet.

A gyakorlatban arról van szó, hogy miképpen kezeljünk egy kockázatos technológiával kapcsolatos fejlesztést vagy a környezet megóvására tett projekteket. Ezeknek az eseteknek a kezelésére az egyik kézenfekvő lehetőség a kétféle diszkontráta alkalmazása: ha azokról a beruházásokról van szó, amikor el kell kerülni a jövő generációknak okozott károkat, akkor nem szabad diszkontálni, minden más esetben a piacra kell hagyni a diszkontráta megállapítását (Davidson 2014). (Persze akkor is diszkontálunk, amikor nem diszkontálunk, csak éppen a diszkontráta zéró.) A másik lehetőség, ha a diszkontálás mellett olyan egyéb intézkedéseket hozunk, amelyekkel csökkenthetők a jövő generációinak terhei. Ezeket az intézkedéseket a társadalomnak kell meghoznia vagy kikényszerítenie a magánberuházóktól. Olyan, már egyes területeken bevezetett előírásokról lehet szó, amelyek pl. növelik egy bányanyitás költségeit azzal, hogy le kell rakni egy biztosítékot a rekultiváció költségeire, vagy olyan intézkedésekről, amikor egy káros technológia környezeti hatásait csökkentő kutatásokba fektet az adott társadalom, de ide tartoznak az atomerőmú nagy aktivitású hulladéklerakóival kapcsolatos kutatások és építkezések is. Bármelyik lehetőséget is valósítjuk meg a fentiek közül, előre soha nem tudjuk, hogy megfelelünk-e az utilitarista elveknek, vagyis nem részesítettük-e előnyben a jelen vagy a jövő generációit. Ez az értékelés, ha egyáltalán képesek vagyunk megmérni a hasznot, amit egy-egy közösségi beruházás okoz, mindig ex post, miközben a beruházások tervezésekor ex ante módon a jövőre kell koncentrálnunk úgy, hogy nem tudjuk, mi következik.

Ha nem akarunk belenyugodni az etikai tehetetlenségünkbe, akkor érdemes egy olyan etikai érvrendszert keresni, aminek célja nem a közgazdaságtan elméletének összebékítése az etikai állásponttal (Davidson 2014), hanem az emberi társadalom jövőjét helyezi középpontba. Jonas (1984) felelősségetikája azt mondja ki, hogy minden generáció számára a legfontosabb etikai parancs az emberiség túlélésének biztosítása úgy, hogy a jövő generációi is méltó életet élhessenek a földön. Akkor, amikor potenciálisan veszélyes technológiákról van szó, nem szabad az azok által jelentett kockázatot oly módon figyelmen kívül hagyni, hogy egy havária, katasztrófa, rendkívüli esemény által okozott kár összegét beszorozzuk az esemény előfordulási 
kockázatával. Ebből az következik, hogy le kell mondani azokról a technológiákról, amelyeknek a hatása a jövő generációinak életfeltételeit veszélyezteti. Mi következik ebből a diszkontálásra? Ha ragaszkodunk a költség-haszon analízishez, akkor ezeknél a technológiáknál alkalmazni kell Weitzman (2009) negatív diszkontrátáját, ami persze azt is feltételezi, hogy nem gondoljuk, hogy a jövő társadalma képes lesz azoknak a környezeti károknak az elhárítására, amit rájuk hagyunk. Erre egyébként jó példa Kelet-Európa vagy Magyarország, ahol a szocialista ipar által tönkretett környezet rehabilitációjára sok helyen a mai napig nem került sor, gondoljunk csak a garéi veszélyes hulladékra vagy arra, hogy az uránbányászatból visszamaradt meddőhányók rekultivációját megfelelő hazai források nélkül az Európai Unió előcsatlakozási alapja, a PHARE-program finanszírozta. Ezek a példák is azt mutatják, hogy nem feltételezhetjük azt, hogy a jövő generációi nálunk gazdagabbak lesznek, hiszen a természeti erőforrásokat és a természeti környezetet ma olyan módon merítjük ki és degradáljuk az emberi tevékenységgel, ami sokkal rosszabb keretfeltételeket biztosít a jövő generációi számára, mint amiben mi élünk.

A jelenleg alkalmazott diszkontálási módszerek és diszkontráták nem alkalmazhatók arra, hogy eldöntsük, milyen beruházásokkal biztosíthatjuk a jövő generációk számára a jogot a tiszta környezethez, a természethez, és így a méltó emberi élethez. Mind az elméleti, mind a gyakorlati problémák azt jelzik, hogy a jövőben valamilyen más diszkontálási filozófiát vagy más jellegű költség-haszon elemzési módszert kell kidolgozni a közösségi beruházások értékelésére. Ehhez segítségül hívhatjuk Jones fentebb említett felelősségetikája mellett Rawls (1985) filozófiáját, ami az igazságosságot helyezi a középpontba. Ha nem a hasznosság utilitarista felfogását helyezzük a középpontba, ahol a „legnagyobb boldogságot” kergetjük (Bentham 1907), hanem a hasznokat és a terheket igazságosan osztjuk meg az egyes generációk között, akkor átlépünk egy más gondolkodási paradigmába. Ebben a paradigmában a károkozás minimalizálása fontosabb lehet (Popper 1952:304) mint a jólét maximalizálása. A diszkontálás szerepe egy ilyen, az igazságosságot axiómaként bevezető költség-haszon elemzésben ma még nem világos. A jövő kutatási iránya lehet ennek a gyakorlatba is átültethető politikák formájában történő kidolgozása.

\section{6. Összefoglalás}

A diszkontálás látszólag pénzügytechnikai múvelet, de valójában a diszkontráta megállapítása mögött komoly etikai és gazdaságfilozófiai megfontolások vannak. Különösen igaz ez akkor, amikor a társadalmilag fontos beruházásoknál alkalmazott költség-haszon elemzések pénzáramainak diszkontálásáról van szó. A jelen tanulmányban összefoglaltuk a diszkontálással kapcsolatos etikai szakirodalom legfontosabb irányzatait. Megállapítottuk, hogy a deskriptív alapú, az egyének diszkontálási szokásait vagy a magángazdasági szereplók viselkedését megfigyelő deskriptív diszkontráta mind episztemológiai, mind etikai szempontból megkérdőjelezhető. Ennek 
oka egyrészt az, hogy a ráta mértékének megállapítása még a magángazdaságban is erősen szubjektív. Másrészt az etikai értékelésnél beleütközünk Hume guillotine-jába, ami azt mondja ki, hogy az, ami van, nem feltétlen jó is. A preskriptív megközelítés esetében a legelterjedtebb utilitarista irányzat abból indul ki, hogy biztosítani kell a diszkontálással mind a jelenlegi, mind a jövőbeli generációk közötti igazságos elosztást. Az utilitarista felfogás egyes vonatkozásait a Ramsey-formula segítségével vizsgáltuk meg. Megállapítottuk, hogy a Ramsey által megadott paraméterek közül a hasznosság különböző felfogásából, illetve a jövőbeli növekedési ráta eltérő becsléséből adódnak azok az ellentmondások, amelyek jellemzik a kardinális és a diszkontált utilitarizmust. A kardinális utilitarizmus szerint ugyanis nem diszkontálhatunk, a diszkontált utilitarizmus szerint pedig diszkontálnunk kell, ha biztosítani akarjuk mind a jelen, mind a jövő generációinak jólétét. A tanulmány végül kitér a társadalmi beruházások esetében a gyakorlatban alkalmazott diszkontrátákra, amelyek megalapozásakor mind a deskriptív, mind a preskriptív elveket segítségül hívják az egyes országokban. Ez a sokféleség együtt az áttekintett szakirodalom legfontosabb, egymással sokszor ellentétes ajánlásaival azt mutatja, hogy a jelenlegi diszkontálási módszerek eltorzítják a társadalom számára fontos beruházások költség-haszon elemzését.

\section{Felhasznált irodalom}

Arrow, K. J. (1999): Discounting, morality, and gaming. In: Portney, P.R. - Weyant, J.P. (Eds.): Discounting and intergenerational equity. Washington: RFF Press, pp. 13-21.

Arrow, K. - Dasgupta, P. - Goulder, L. - Daily, G. - Ehrlich, P. - Heal, G. - Levin, S. - Maler, K.G. - Schneider, S. - Starrett, D. - Walker, B. (2004): Are we consuming too much? Journal of Economic Perspectives, 18(3): 147-172. https://doi.org/10.1257/0895330042162377

Arrow, K. - Cropper, M. - Gollier, C. - Groom, B. - Heal, G. - Newell, R. - Nordhaus, W. Pindyck, R. - Pizer, W. - Portney, P. - Sterner, T. - Tol, R. - Weitzman, M. (2012): How should benefits and costs be discounted in an intergenerational context? The views of an expert panel. Discussion Paper, Resources for the Future: 12-53.

Baumol, W.J. (1968): On the social rate of discount. American Economic Review, 58(4): 788-802.

Bélyácz Iván (2010): Kockázat vagy bizonytalanság? Elmélettörténeti töredék a régi dilemmáról. Közgazdasági Szemle, 57 (július-augusztus): 652-665.

Bentham, J. (1907): Introduction to the principles of morals and legislation. London: Oxford Clarendon Press. http://fs2.american.edu/dfagel/www/Philosophers/Bentham/ principlesofMoralsAndLegislation.pdf. Letöltés ideje: 2017. október 24. 
Broome, J. (1994): Discounting the Future. Philosophy \& Public Affairs, 23(2): 128-156. https://doi.org/10.1111/j.1088-4963.1994.tb00008.x

BWE (2015): Gutachtliche Stellungnahme zur Bewertung der Rückstellungen im Kernenergiebereich. https://www.bmwi.de/Redaktion/DE/Downloads/S-T/ stresstestkernenergie.pdf?_blob=publicationFile \&v=3

CEAI (2017): Discounting for Public Policy: Theory and Recent Evidence on the Merits of Updating the Discount Rate. Council of Economic Advisers Issue Brief January 2017. https://obamawhitehouse.archives.gov/sites/default/files/page/files/201701_cea_ discounting_issue_brief.pdf. Letöltés ideje: 2017. október 24.

Cline, W.R. (1992): The economics of global warming. Washington, D.C.: Institute for International Economics.

Dasgupta, P. (2008): Discounting climate change. Journal of risk and uncertainty, 37(2): 141-169. https://doi.org/10.1007/s11166-008-9049-6

Davidson, M.D. (2014): Zero discounting can compensate future generations for climate damage. Ecological Economics, 105: 40-47. https://doi.org/10.1016/ j.ecolecon.2014.05.018

Djukic, M. - Jovanoski, I. - Ivanovic, O.M. - Lazic, M. - Bodroza, D. (2016): Cost-benefit analysis of an infrastructure project and a cost-reflective tariff: A case study for investment in wastewater treatment plant in Serbia. Renewable and Sustainable Energy Reviews, 59(June): 1419-1425. https://doi.org/10.1016/j.rser.2016.01.050

Fisher, I. (1930): The Theory of Interest. New York: Kelley and Millman.

Frederick, S. (2006): Valuing Future Life and Future Lives: A Framework for Understanding Discounting. Journal of Economic Psychology, 27(5): 667-680. https://doi.org/10.1016/ j.joep.2006.05.007

Freeman, M.C. - Groom, B. (2015): Positively gamma discounting: Combining the opinions of experts on the social discount rate. Economic Journal, 125(585): 1015-1024. https://doi.org/10.1111/ecoj.12129

Gaus, G. (2012): The Order of Public Reason: A Theory of Freedom and Morality in a Diverse and Bounded World. Cambridge: Cambridge University Press.

GLO (2017): United Nations Convention to Combat Desertification. 2017. The Global Land Outlook, first edition. Bonn, Germany.

Gollier, C. (2011): Pricing the future: The economics of discounting and sustainable development. Princeton University Press, pp. 1-210. 
Gollier, C. - Hammit J.K. (2014): The Long-Run Discount Rate Controversy. Annual Review of Resource Economics, Vol. 6: 273-295. https://doi.org/10.1146/annurevresource-100913-012516

Greaves, H. (2017): Discounting for Public Policy. A Survey. Economics and Philosophy, 33(3): 391-439. https://doi.org/10.1017/S0266267117000062

Groom, B. - Koundouri, P. - Panopoulou, E. - Pantelidis, T. (2007): Discounting the distant future: how much does model selection affect the certainty equivalent rate? Journal of Applied Econometrics, 22(3): 641-656. https://doi.org/10.1002/jae.937

Groom, B. (2017): International Guidelines on Social Discount Rates. http://www.strategie. gouv.fr/sites/strategie.gouv.fr/files/atoms/files/07_ben_groom_international_guidelines_ on_social_discount_rates.pdf. Letöltés ideje: 2017. október 24.

Hampicke, U. (2011): Climate change economics and discounted utilitarianism. Ecological Economics, 72: 45-52. https://doi.org/10.1016/j.ecolecon.2011.08.028

Harsányi, J. (1955): Cardinal Welfare, Individualistic Ethics, and Interpersonal Comparisons of Utility. Journal of Political Economy, 63(4): 309-321. https://doi.org/10.1086/257678

Hatfield, J.L. (2016): Increased Temperatures Have Dramatic Effects on Growth and Grain Yield of Three Maize Hybrids. Agricultural \& Environmental Letters, 1(1), 150006.

HM Treasury (2003, updated July 2011): The Green Book - Appraisal and evaluation in central government. London.

Hume, D. (1739): A Treatise of Human Nature. https://people.rit.edu/wlrgsh/HumeTreatise.pdf Jagannathan, R. - Matsa, D.A. - Meier, I. - Tarhan, V. (2016). Why do firms use high discount rates? Journal of Financial Economics, 120(3): 445-463. https://doi.org/10.1016/ j.jfineco.2016.01.012

Jevons, W. (1911): The Theory of Political Economy. Macmillan, London.

Jonas, H. (1984): Das Prinzip Verantwortung. Versuch einer Ethik für die technologische Zivilisation. Frankfurt a.M.

Kant, I. (1995): Kritik der praktischen Vernunft. Reclam. Stuttgart.

Knight, F.H. (1921): Risk, Uncertainty, and Profit. Hart, Schaffner \& Marx-Houghton Mifflin Co., Boston, MA. 
Lewandowsky, S. - Freeman, M.C. - Mann, M.E. (2017): Harnessing the uncertainty monster: Putting quantitative constraints on the intergenerational social discount rate. Global and Planetary Change, 156(September): 155-166. https://doi.org/10.1016/ j.gloplacha.2017.03.007

Liu, L. (2011): From the Shadow Price of Capital to the Marginal Cost of Funds: In Search of the Implementation of a Principle. Journal of Public Economic Theory, 13(3): 369-389. https://doi.org/10.1111/j.1467-9779.2011.01504.x

Malkin, J. - Vildavsky, A. (1991): Why the Traditional Distinction between Public and Private Goods Should be Abandoned. Journal of Theoretical Politics, 3(4): 355-378. https://doi.org/10.1177/0951692891003004001

Nordhaus, W. (2006): The "Stern Review" on the Economics of Climate Change. Journal of Economic Literature, 45(3): 686-702. https://doi.org/10.3386/w12741

Nordhaus, W. (2008): A Question of Balance: Weighing the Options on Global Warming Policies. Yale University Press.

Odum, H.T. (1983): System Ecology an Introduction. J. Wiley, NY.

OXERA (2002): A Social Time Preference Rate for Use in Long-term Discounting. Oxera Consulting Ld. p80.

Pearce, D. - Ulph, D. (1995): A social discount rate for the United Kingdom. Working paper No 95-01, CSERGE, University College London, and University of East Anglia, pp. 1-22.

Popper, K.R. (1952): The Open Society and Its Enemies, Volume II., 1st Edition. Routledge \& Kegan Paul, London. https://monoskop.org/images/6/6d/Popper_Karl_The_Open_ Society_and_its_Enemies_The_High_Tide_of_Prophecy_Vol_2_1st_ed.pdf. Letöltés ideje: 2017. október 24.

Rambaud, S. - Torrecillas, M.J.M. (2006): Social discount rate: a revision. Anales de Estudios Económicos y Empresariales, XVI: 75-98. http://dialnet.unirioja.es/servlet/ articulo?codigo=2315261. Letöltés ideje: 2017. október 24 .

Ramsey, F.P. (1928): A mathematical theory of saving. Economic Journal, 38(152): 543-559. https://doi.org/10.2307/2224098

Ray, D.K. - Mueller, N.D. - West, P.C. - Foley, J.A. (2013): Yield Trends Are Insufficient to Double Global Crop Production by 2050. PLoS ONE 8(6): e66428. pp. 1-8. https://doi.org/10.1371/journal.pone.0066428

Rawls, J. (1985): Justice as Fairness: Political not Metaphysical. Philosophy and Public Affairs, 14(3): 223-251. 
Revesz, R.L. - Shahabian, M.R. (2011): Climate change and future generations. Southern California Law Review, Vol. 84: p. 1097.

Sen, A.K. (1973): On Economic Inequality. Clarendon Press, Oxford. https://doi.org/10.1093/0198281935.001.0001

Sinnot-Armstrong, W. (2015): Consequentialism. In: Zalta, E.N. (ed.): The Stanford Encyclopedia of Philosophy. Winter 2015 Edition.

Stern, N. (2007): The Economics of Climate Change: The Stern Review. Cambridge University Press. https://doi.org/10.1017/CBO9780511817434

Szűcsné Markovics Klára (2014): A kalkulativ kamatláb (diszkontráta) meghatározásának ajánlott és alkalmazott módszerei. Controller info, 2(4): 8-13.

Tabi Andrea (2012): A társadalmi diszkontráta jelentősége a fogyasztás időbeli ütemezésében. In: Fenntartható fogyasztás? Trendek és lehetőségek Magyarországon. OTKA 68647 kutatás eredményei. AULA, Budapest, pp. 142-173.

Tabi Andrea - Csutora Mária (2011): A temporális diszkontálási szokások vizsgálata a társadalmi diszkontráta és a társadalmi preferenciák kapcsolata. pp. 1-19. http://unipub. lib.uni-corvinus.hu/495/1/tarsdiszkont_Tabi_Csutora20110610.pdf

Tainter, J.A. (1988): The Collapse of Complex Societies. Cambridge University Press.

Trostel, P.A. - Taylor, G.A. (2001): A theory of time preference. Economic Inquiry, 39(3): 379-395. https://doi.org/10.1093/ei/39.3.379

Weisbach, D. - Sunstein, C.R. (2009): Climate change and discounting the future: a guide for the perplexed. Yale Law and Policy Review, 27: 433-458.

Weitzman, M.L. (1998): Why the far-distant future should be discounted at its lowest possible rate? Journal of Environmental Economics and Management, 36(3): 201-208. https://doi.org/10.1006/jeem.1998.1052

Weitzman, M.L. (2001): Gamma discounting. American Economic Review, 91(1): 260-271. https://doi.org/10.1257/aer.91.1.260

Weitzman, M.L. (2009): On modeling and interpreting the economics of catastrophic climate change. Review of Economics and Statistics, 91(1): 1-19. https://doi.org/10.1162/rest.91.1.1

Weitzman, M.L. (2012): The Ramsey Discounting Formula for a Hidden-State Stochastic Growth Process. Environmental and Resource Economics, 53(3): 309-321. https://doi.org/10.1007/s10640-012-9594-y 